Dr VLADIMIR PETROVIĆ, naučni saradnik

Institut za savremenu istoriju

UDK 323(497.11)"1987/1991"

Beograd, Trg Nikole Pašića 11

\title{
ULOGA MEDIJA U UČVRŠĆENJU VLASTI SLOBODANA MILOŠEVIĆA ${ }^{*}$
}

\begin{abstract}
APSTRAKT: Nastojeći da osvetli ulogu medija u učvršćenju režima Slobodana Miloševića, članak skicira razvoj medijske scene u posleratnoj Jugoslaviji i fokusira se njen izgled posle smrti Josipa Broza Tita, a posebno se analizira prestrojavanje srpskih sredstava javnog informisanja uoči, tokom i posle Osme sednice CK SKS, njihovo svrstavanje uz ličnost Slobodana Miloševića, uloga u konsolidaciji njegove vlasti i njenom prerastanju u režim.
\end{abstract}

Ključne reči: Slobodan Milošević, srpski mediji, Osma sednica CK SKS, propaganda

„Godinama je najveću pažnju posvećivao sredstvima informisanja, naročito televiziji“, piše o Slobodanu Miloševiću jedan od njegovih najbližih saradnika iz vremena uspona, Borisav Jović: „Lično je odabirao glavne urednike novina i informativnih programa, a pogotovo direktora radija i televizije. Možda nigde kao u ovoj oblasti nije na direktnoj vezi držao sve urednike koji su 'hranili' javnost vestima, komentarima i uopšte informacijama. Bio je duboko ubeđen da građani svoje gledanje na političku situaciju formiraju na osnovu onoga što se njima servira, a ne prema njihovom stvarnom materijalnom i političkom položaju.

Ono što nije objavljeno, nije se ni dogodilo - to je bila Miloševićeva deviza. “" Miloševićev stav prema medijima direktno je proizilazio iz ličnog iskustva. Imao je jake razloge da tako oceni (i ceni) ulogu medija, koji su odigrali ključnu ulogu u učvršćivanju njegove vlasti i njenom prerastanju u režim.

" Rad je deo projekta Srpsko društvo u jugoslovenskoj državi u 20. veku - Između demokratije i diktature (177016) koji finansira Ministarstvo prosvete, nauke i tehnološkog razvoja Republike Srbije.

${ }^{1}$ Borisav Jović, Knjiga o Miloševiću, Beograd 2001, 13. 


\section{Grananje medijske sfere u socijalističkoj Jugoslaviji i sistemi njenog nadzora}

Manipulacija medijima, razume se, nije bila Miloševićevo otkriće. Medijski sistem SFR Jugoslavije i SR Srbije začet je u ratnom kontekstu. O značaju koji je partizanski pokret pridavao informativnoj sferi svedoči i činjenica da je na Drugom zasedanju AVNOJ-a novembra 1943. prva institucija stvorena odmah posle Nacionalnog komiteta oslobođenja Jugoslavije (NKOJ) bila Telegrafska agencija Nove Jugoslavije (Tanjug). ${ }^{2}$ Partijska glasila poput Borbe i Proletera nastavila su da izlaze tokom rata, kao i veliki broj biltena, plakata i drugih propagandnih sredstava. U neposrednom posleratnom periodu ovaj udarnički trend je nastavljen. Iako je Zakon o štampi, kao i Ustav iz 1946. zabranjivao cenzuru i garantovao slobodu štampe, postojali su efikasni načini da se ona ograniči. ${ }^{3}$ Nacionalizacijom grafičkih preduzeća, štamparija, litografija i kinematografa, država i partija su ovu sferu stavile pod potpunu kontrolu. Koordinaciju je vršilo Ministarstvo za informacije, na čijem čelu se nalazio Vladislav Ribnikar, ali i Agitprop komisija direktno podređena CK KPJ, pod rukovodstvom Milovana Đilasa. ${ }^{4}$ Zahuktavanje propagandne delatnosti bilo je važan segment preuzimanja pune kontrole nad društvom. Tako se broj listova $u$ Jugoslaviji penje sa 97 (1945) na 248 (1948). Osim nekoliko verskih publikacija, sva su ta glasila bila pod direktnom ili posrednom kontrolom KPJ. ${ }^{5}$ Partijski organ Borba prerasta u dnevni list, i u tom periodu doseže vrhunac tiraža od 650.000 primeraka. Upravo je ta medijska centralizacija doprinela odolevanju sovjetskom pritisku prilikom krize oko Rezolucije Informbiroa 1948-1949.

U godinama posle Informbiroa, u nastojanju da se pokaže da je jugoslovenski komunizam drugačiji od sovjetskog, menja se i raslojava i medijska scena. Redakcija Borbe je 1953. pokrenula Večernje novosti, a pisci iz Mladog borca obnovili su NIN 1951. godine. Osnovnim zakonom o novinskim preduzećima i ustanovama iz 1956, institut osnivača se prenosi sa države na društveno-političke zajednice, pretežno organizacije socijalističkog saveza. Tako Borba postaje organ SSRNJ, a Politika organ SSRNS. Naravno,

${ }^{2}$ Stevan Nikšić, Oslobođenje štampe, Beograd 1982, 125.

${ }^{3}$ Zakon o štampi je ostao na snazi do 1960. Drugi propisi koji su regulisali ovu oblast u neposrednom posleratnom periodu: Odluka o obaveznom dostavljanju štampanih stvari na području Jugoslavije (1945); Uredba o organizaciji radiodifuzne službe (1946); Pravilnik o prijavljivanju radio-aparata (1946).

${ }^{4}$ Više u: Ljubodrag Dimić, Agitprop kultura. Agitpropovska faza kulturne politike $u$ Srbiji 1945-1952, Beograd 1988, 31-54.

${ }^{5}$ S. Nikšić, $n$. d., 129. O Zakonu o štampi piše Lj. Dimić, $n$. d., 154-156, a posebno Mihailo Bjelica, Mediji i politička moć. Novinarstvo u Srbiji 1945-1997, Beograd 1997, 21-26. 
ove su promene bili pre administrativne nego stvarne, partija je čvrsto držala medijske konce u rukama. ${ }^{6}$

Iako je jugoslovenska štampa postajala slobodnija od „blokovske“, granice su jasno postavljene. O ovoj temu je ilustrativno govorio 1957. šef države Josip Broz Tito: „Mi ne možemo sada dozvoliti da vlada naše zemlje vodi jednu spoljnu politiku, a da pojedini novinar, zbog toga što mora da razvija svoje misli, smatra da je on iznad svega, da mora da stvara javno mišljenje i da radi toga ruši onu politiku koju inauguriše i sa kojom se slaže naš narod". ${ }^{7}$ Dve godine kasnije, ponovo se osvrnuo na pitanje slobode štampe i njenog ograničavanja: „Naša štampa je slobodna, kao što mora da bude slobodna u jednoj zemlji koja stvara svoj život na principima prave socijalističke demokratije. Ali, ona mora biti strogo principijelna i u skladu sa politikom naše narodne vlasti i nastojanjima da se ostvaruju svi zadaci koji vode u socijalizam“. ${ }^{8}$ Posledično, po oceni Mihaila Bjelice, „u vreme Titove vladavine stvoren je u Jugoslaviji sistem javnog informisanja koji je po mnogo čemu bio specifičan u svetu. Gledan izdaleka, sistem je izgledao skoro idealan. Najvišim normativnim i programskim dokumentima garantovana su radnim ljudima i građanima takoreći sva poznata prava i slobode u oblasti informisanja (...) Međutim, ako se sistem osmotri iznutra, nije teško zapaziti da je on svo vreme funkcionisao na stari agitpropovski način. Za većinu garantovanih prava nisu bili predviđeni mehanizmi kako se oni ostvaruju u praksi. To je poznati nesklad između normativnog i stvarnog."

Tako je Zakon o štampi i drugim vidovima informacija donet 1960. predviđao slobodne medijske ustanove kojima se upravlja po načelima društvenog samoupravljanja, zarad ostvarenja prava građana na informisanje. Ističe se i sloboda štampe, ali i njena dužnost da građane pravovremeno, potpuno i valjano informiše. ${ }^{10}$ Te godine je u zemlji izlazilo 904 listova sa ukupnim tiražom od 629.476.000, a broj časopisa je premašio hiljadu. Ovaj

${ }^{6}$ U novine se stizalo po partijskoj direktivi. Aleksandar Nenadović se seća kako ga je u Politiku uputio Milić Bugarčić, nadređeni u partijskom Univerzitetskom komitetu: „Danas sam dobio poruku da češ i ti, kako su drugovi odlučili, kao mlađi novinarski saradnik biti uključen u grupu koju CK Srbije šalje u Politiku (...) Na urednička mesta, približno u isto vreme (tokom 1952), došli su i partijski funkcioneri višeg ranga. Mita Miljković, član srpskog CK, postavljen je za glavnog i odgovornog urednika Politike." - Aleksandar Nenadović, Glavni urednik. „Politika“ i pad srpskih liberala, 1969-1972, Beograd 2003, 33-35. Pod partijskim okriljem se otvara i nova institucija koja služi formiraju kadrova u ovoj oblasti. Up. Dragomir Bondžić (prir.), Novinarska i diplomatska visoka škola u Beogradu 1948-1953, Beograd 2013. 1960, IX, 21.

${ }^{7}$ J. B. Tito, O diskusiji na V plenumu Saveznog odbora SSRN, Sabrana dela, Zagreb

${ }^{8}$ J. B. Tito, Pismo Savezu novinara, n. d., X, 299.

${ }^{9}$ M. Bjelica, $n$. d., 53-55.

${ }^{10}$ S. Nikšić, $n$. d., 154-59. 
zakon je osim štampe regulisao i druge vidove informacija, prepoznajući domete radio-difuzne revolucije. Radio je već tokom Drugog svetskog rata odigrao značajnu ulogu u propagandnoj delatnosti, programima Radio Londona na jugoslovenskom jeziku, ili radio stanice "Slobodna Jugoslavija“ koja je emitovala sa teritorije SSSR-a. Prepoznajući važnost ovog medija, nove vlasti osnivaju posle rata Savezni komitet za radio difuziju koji koordinira radom šest republičkih i dve pokrajinske matične radio stanice, a Radio Jugoslavija postoji do 1953. godine, kada se deli po republičkim šavovima, pa tako nastaju Radio Beograd (1944), Radio Zagreb i Radio Ljubljana, nešto docnije i Radio Novi Sad (1949) čiji rad koordinira Jugoslovenska radio-difuzija, a reguliše Zakon o radio-difuznim stanicama iz 1955. godine. Za samo jednu deceniju, broj registrovanih radio-aparata povećan je sa 422.000 (1953) na 2.300 .000 (1963). ${ }^{11}$ Radio Beograd je do 1970. godine emitovao tri programa, a osnovan je i Studio B kao radio novinara Borbe.

U ovom periodu pojavljuje se i novi, neobično važan medij - televizija. Mogućnost televizijskog prenosa predstavljena je Beograđanima još na izložbi o Nikoli Tesli u Bezistanu 1955. godine. Već 8. juna 1956. Savezno izvršno veće donosi odluku o dodeljivanju sredstava za izgradnju televizijske mreže u Jugoslaviji. ${ }^{12}$ Informativni program je isprva bio pod okriljem federacije Saveznog saveta za radiodifuziju i televiziju, koji je usmeravao rad Centralne informativne redakcije. Iako je osnovano zajedničko programsko telo za televizijski program, ubrzo se zbog jezičkih i političkih razloga prelazi sa koncepta zajedničkog na koncept koordiniranog programa, pa se u SFRJ izdvajaju tri centra - TV Zagreb (1956), TV Beograd (1958) i TV Ljubljana (1958). ${ }^{13}$ Razvija se i Radio Beograd, koji osniva Drugi (1965) pa Treći program (1969). NIP Borba osniva Studio B 1970. godine, a od 1973, televizijski program u boji se emituje svakodnevno. ${ }^{14}$ Nije se razvijao samo program, već i kadrovi. Kako piše Aleksandar Nenadović, na scenu je stupila nova generacija novinara, unoseći vidne promene kroz „oprezna nastojanja redakcije da profesionalnim, selektivnim postupkom - kojim se, dakako nije poništavao jednopartijski informativni monopol - korak po korak racionalizuje i 'najosetljivije', to jest, političko izveštavanje sa doma-

${ }^{11}$ Aleksandar Spasić, Kratak pregled istorije radiodifuzije u Jugoslaviji, Beograd 1976, 70-90.

${ }^{12}$ Videti: Igor Leandrov, Pre početka. Sećanja na pripreme za uvođenje televizijskog programa u Beogradu, Prilozi za istoriju Televizije Beograd, TVB Beograd 1986, tom II; Up. I Rodoljub Žižić, Kroz ekran svet, Prilozi za istoriju Televizije Beograd, Beograd 1986, tom III, Up. Vasilije Popović et alia, Iz istorije Televizije Beograd, TV Beograd 1984, 102-103.

${ }^{13}$ Prvi eksperimentalni program TV Beograd emitovan je u subotu, 23. avgusta 1958, iz studija na Sajmištu, kada je gledaoce pozdravio voditelj Mića Orlović. - I. Leandrov, n.d., 5 .

${ }^{14}$ A. Spasić, n. d., 92-95. 
će scene (...) Granicu tih mogućnosti u Politici kao i u drugim medijima, širile su, ili sužavale, opšte političke prilike unutar vladajuće nomenklature, pre svega partijske." ${ }^{\prime 15}$

Granice ovih mogućnosti su se naglo sužavale u kriznim periodima, poput studentskih protesta 1968, nakon kojih Izvršni biro Predsedništva SKJ kritikuje „svojevrstan fetiš autonomije štampe (...) Razvilo se shvatanje da usmerenost i sadržina listova, radio i TV programa zavise isključivo od redakcija, odnosno ponašanja novinara“. Zaključuje se da je „neophodno u većoj meri celokupni sistem informisanja tretirati kao sastavni deo političkog sistema i političke i društvene odgovornosti“ ${ }^{16}$ Jedna od posledica ovakvog pristupa bila je i ta da su mediji ostali blisko vezani za političke nomenklature, sa kojima su se uspinjali i padali. Dobar primer za to je pad Nikezićevog rukovodstva u Srbiji 1972. Hajku je najavio Dragoslav Draža Marković, čiju izjavu je prenela Politika, 26. oktobra 1972, pod naslovom Znaju se najpreči poslovi: „Ispitaće se struktura kadrova u sredstvima informisanja." Ističući da „opravdana kritika, tačno upućena na beogradsku štampu, u rečima druga Tita obavezuje sve u ovoj republici na hitno preduzimanje mera“, Marković je najavio „likvidiranje monopola određenih struktura i pojedinaca u društvu nad sredstvima informisanja i likvidiranje monopola pojedinaca u sredstvima informisanja“. ${ }^{17}$ Marković istovremeno beleži u svom dnevniku: „Biće nužno naći zadovoljavajuća rešenja u sredstvima informisanja. U RTV Beograd, za generalnog direktora, umesto Zdravka Vukovića, ići iće svakako Milan Vukos. Ko će na mesto Saše Nenadovića u Politici i F. Barbijerija u NIN-u? M. Stamenković i ne misli da treba još da ide iz Večernjih novosti. Po mom uverenju, biće nužna zamena i Lj. Veljkovića u Ekonomskoj politici. Treba razmišljati o svemu. Neće biti baš jednostavno naći zadovoljavajuća rešenja svuda. Možda bi dobro bilo ići svuda, privremeno, ne na konačna rešenja, već postaviti samo v. d. glavnih urednika i urednika". ${ }^{18}$

Nekoliko dana kasnije, rečeno je učinjeno, i Marković u dnevniku beleži: „Saša Nenadović (Politika), Frane Barbijeri (NIN) i Era Ilić (RTV Beograd) dali su ostavke. Za vršioce dužnosti imenovani su: Voja Đukić (Politika), Uča Milivojević (NIN) i Lj. Zečević (RTB). Vrlo je naglašeno da to ne znači nikakvo prejudiciranje rešenja. Bilo je važno, međutim, razjasniti se i dogovoriti hitno oko v. d. rukovodećih funkcija u tim radnim organizacijama, kako bi se u bukvalnom smislu 'preuzela vlast' u toj značajnoj obla-

\footnotetext{
${ }^{15}$ A. Nenadović, n. d., 55.

${ }^{16}$ Isto, 57-58.

${ }^{17}$ Cit. prema: A. Nenadović, n. d., 245-258.

${ }^{18}$ Dragoslav Draža Marković, Život i politika 1967-1978, 29. oktobar 1972, Beograd
} 1978, knj. I, 396. 
sti“ ${ }^{19}{ }^{19}$ Ostalo je još da ove odluke potvrde formalni osnivači, pa je tako koji dan docnije „predsedništvo Republičke konferencije SSRN Srbije prihvatilo u svojstvu osnivača Novinsko-izdavačkog preduzeća Politika ostavku glavnog i odgovornog urednika Aleksandra Nenadovića."20 Brzina ove čistke pokazala je istinske razmere politizacije medija. Slavoljub Đukić sumira njene efekte, kojima je srpsko novinarstvo preko noći lišeno najsposobnijih novinara: „Jednim potezom pera smenjeni su, ili pod pritiskom vlasti dali ostavke, svi urednici vodećih glasila. “21 Ova čistka je uzrokovala dalekosežnu eroziju samosvesti. Opredelila je stavove i ponašanje nove klape glavnih urednika srpskih medija, koji su nastojali da osluškuju političke vetrove bez izlaganja riziku koji je oduvao njihove prethodnike.

Ubrzo su se osetile posledice ove krize. Sistem je postajao konfuzan i upadao u protivurečnosti: „Ustavom SFRJ (čl. 167) i Zakonom o štampi bila je zajamčena sloboda štampe i drugih vidova informisanja. Za objavljivanje informacija nije bila potrebna prijava ni prethodno odobrenje. Cenzura nije postojala, ili bolje rečeno zakoni kažu da ne postoji. Zakonodavac izuzetak predviđa 'u slučaju ratnog stanja ili kad je aktom nadležnog organa utvrđeno da postoji neposredna ratna opasnost' (čl. 3. Zakona o štampi). Građanima se daje pravo da se koriste sredstvima informisanja radi sopstvenog obavještavanja, da izražavaju i objavljuju svoja mišljenja, šire informacije, izdaju novine i druge oblike štampe kao i pravo da učestvuju u upravljanju sredstvima javnog saopštavanja informacija pod uslovima koje propisuje zakon. Ovim se pravom na smije koristiti u cilju rušenja socijalističkog demokratskog uređenja utvrđenog Ustavom, ugrožavanja mira, ravnopravne međunarodne saradnje i nezavisnosti SFRJ, raspirivanja nacionalne, rasne ili vjerske mržnje. Ovom zabranom obuhvaćeno je i podsticanje na vršenje krivičnih djela, vrijeđanje časti i ugleda građana, javni moral, sve što može da nanese štetu vaspitanju djece i omladine ili da nanese štetu interesima društvene zajednice. Slična ograničenja sadrži i više članova saveznog Zakona, kao i čl. 1. i 2. Zakona o sprečavanju zloupotrebe slobode štampe i drugih vidova informisanja iz 1976. godine." 22 Prvi član ovog zakona sankcioniše zloupotrebu „slobode štampe i drugih vidova informisanja radi rušenja osnova socijalističkog samoupravnog demokratskog uređenja utvrđenog Ustavom SFRJ, ili ugrožavanje nezavisnosti zemlje“. Sličnu svrhu su indirektno imali i članovi 116, 134, 136, 150 i 157 saveznog Krivičnog zako-

${ }^{19}$ D. Marković, n. d., 3. novembar 1972, 397.

${ }^{20}$ A. Nenadović, $n$.d., 252.

${ }^{21}$ Slavoljub Đukić, Političko groblje, Beograd 2010, 189.

${ }^{22}$ Mirjana Nadazdin Defterdarević, Pravo i sloboda informisanja. Dometi i ograničenja. Razvoj komunikacijskih sistema i procesa u Bosni i Hercegovini, Most. Časopis za obrazovanje, nauku i kulturu, br. 105, jul-avgust 1998, http://www.most. ba/016/028.htm 
na, a posebno njegov član 133, posvećen krivičnom delu neprijateljske propagande. Međutim, u relativnom šarenilu saveznih, republičkih i lokalnih medija koji su deklarativno radili kao autonomne organizacije udruženog rada, nije uvek bilo lako pogoditi kada se i kako prelazi ova zakonska barijera.

Takav sistem je bio posebno loše opremljen da reaguje na krizne situacije, što se osetilo ubrzo posle Titove smrti. Eskalacija krize na Kosovu početkom aprila 1981, karakterisana izgubljenim životima, zavođenjem vanrednog stanja i vojnom intervencijom, bila je praćena i embargom na informacije. Na partijskim sastancima slavljena je medijska reakcija na krizu.

Radovan Pantović je sa čela Programskog saveta RTB-a tvrdio da su „novinari izvršili sve svoje zadatke koji su im se nametnuli u toku izveštavanja o kontrarevoluciji na Kosovu i akcijama društva, pre svega Saveza komunista.“23 Realnost je, međutim, bila drugačija: „Jedan jugoslovenski dnevni list doneo je 1. aprila 1981. godine, sasvim hladnokrvno, članak o velikim turističkim mogućnostima SAP Kosovo. Idućeg dana i sva ostala štampa prenela je agencijsku informaciju o povećanju dnevnog dodatka $u$ pokrajini Kosovo. Informativne emisije jugoslovenskih televizijskih stanica obilovale su tih dana vestima o događajima širom sveta - prvi minuti posvećivani su po pravilu sukobima policije i obojenog stanovništva u Londonu i sličnim uličnim neredima u Briselu. O onome što se upravo zbivalo na Kosovu nije bilo ni reči“ ${ }^{24}$

Mediji su itekako podbacili u pokrivanju ovih događaja, ne usuđujući se da o njima izveštavaju dok se nije utvrdila njihova politička kvalifikacija. Međutim, jednom kada je jugoslovenski partijski vrh osudio albanske demonstracije kao izraz kontrarevolucije, najuticajnija srpska glasila su se nadmetala u osudama albanskog iredentizma, dolivajući ulje na vatru. $^{25}$

Posle ustavnih promena 1974, najdirektniji uticaj na medije dolazio je iz republičkih centara, što je umesto liberalizacije dovelo do republičke parcelizacije medijskog prostora. „Stara Juga se zauvek raspadala. I štampa je izgubila raniji izgled. Posle više decenija prisilnog ućutkivanja, nastala je gladna trka da kažemo ono što ranije nismo mogli reći. “26 Prema Ognjenu Pribićeviću, u drugoj polovini osamdesetih je „došlo do značajnih promena $\mathrm{u}$ sistemu informisanja. Stari sistem se raspao, a novi koji nastaje predsta-

${ }^{23}$ Cit. prema: Rade Veljanovski, Zaokret elektronskih medija, u: Nebojša Popov (prir.), Srpska strana rata. Trauma i katarza u istorijskom pamćenju, Beograd 2002. knj. II, 180.

${ }^{24}$ S. Nikšić, n. d., 229.

${ }^{25}$ Videti: Vladimir Petrović, Ekstremizacija jugoslovenskog političkog govora od smrti Josipa Broza Tita do Osme sednice, u: Momčilo Pavlović, Dejan Jović, Vladimir Petrović (prir.), Slobodan Milošević: Put ka vlasti. Osma sednica CK SKS, Beograd 2008, 83-92.

${ }^{26}$ S. Đukić, n. d., 225-226. 
vlja mešavinu starog i novog.“27 Prema Zakonu o osnovama sistema javnog informisanja SFRJ iz 1985, društveno-političke zajednice i organizacije su mogle osnovati novinsku ili radiodifuznu organizaciju, ali uz pribavljeno mišljenje SSRN (Socijalističkog saveza radnog naroda), Sindikata ili Saveza omladine, čime se čuvao refleks partijske kontrole nad medijskom sferom uspostavljen 1945. godine. Zakonom je bila predviđena i zabrana rasturanja štampe ukoliko „se iznose ili prenose neistinite i alarmantne vesti ili tvrdnje kojima se ugrožava ili bi se mogao ugroziti javni red ili mir ili uznemiriti javnost".

Naravno, nije manjkalo inicijativa da se sistem transformiše. „Posle Titove smrti počela su se postavljati razna pitanja o funkcionisanju političkog i informativnog sistema, među kojima i pitanje položaja i uloge profesionalnih novinara. Na novinarskim skupovima mogle su se čuti izjave, valjda prvi put posle Drugog svetskog rata, da ova profesija ne bi smela da bude transmisija Saveza komunista." ${ }^{28}$ To je bilo lakše reći nego sprovesti u delo. Po podacima Saveza novinara Jugoslavije, u SFRJ je 1982. radilo 11.000 novinara, od kojih u Srbiji 3.800. Od ovog broja preko $75 \%$ bili su članovi SKJ. U izdanjima NIP Borbe radilo je oko 450 novinara, od kojih su $65 \%$ bili članovi partije. U NIP Politika od oko 400 bilo je $70 \%$ članova partije, u Radio Beogradu 300 novinara, u Televiziji Beograd 300 (80\% članova partije, a u Tanjugu od 250 zaposlenih $88 \%$ imalo je partijsku knjižicu. ${ }^{29}$ Iako je Agitprop odavno raspušten, nadzor nad medijima i dalje je sprovodila Komisija Predsedništva CK SKJ za propagandnu i informativnu delatnost, a ni policija nije bila manje zainteresovana.

Kako piše Slavko Ćuruvija, „u Sedmoj upravi SSUP-a postojalo je odeljenje zaduženo za kontrolu medija, koje je u svakoj redakciji imalo svoje obaveštajce i to po sistemu: jedan policajac na tri novinara, zahvaljujući čijoj delatnosti je policija promptno, na svakih deset minuta dobijala izveštaje šta se gde događa." ${ }^{30}$ Ovi sistemi kontrole ipak nisu funkcionisali kao ranije. „Nespremna za ma kakve demokratske reforme, vladajuća partija nastojala je da i dalje vlada i drži sve konce u svojim rukama na isti način kao i ranije. Međutim, kako je vreme odmicalo, otpori jednopartijskom načinu vladanja postajali su sve jači. Sa raznih strana dolazile su kritike, kako prakse tako i teorije. Jedan za drugim dovedeni su u pitanje svi principi na kojima je zasnovan Program Saveza komunista - vodeća uloga partije,

${ }^{27}$ Ognjen Pribićević, Promene u sistemu informisanja u Jugoslaviji, Novinarstvo, 1$1991,66$.

${ }^{28}$ M. Bjelica, $n$. d., 55.

${ }^{29}$ M. Bjelica, $n$. d., 48-49.

${ }^{30}$ Predrag Popović, Oni ne praštaju, Poslednja ispovest Slavka Ćuruvije, Beograd 2001, 165. 
demokratski centralizam, samoupravni socijalizam, delegatsko odlučivanje. “31 Sistem je bio na prekretnici.

\section{Stvaranje vođe - srpski mediji i uspon Slobodana Miloševića}

Odgovor na ovaj izazov razlikovao se u različitim delovima Jugoslavije. „Tokom 1984. godine partijski komiteti imali su obavezu da organizuju rasprave o problemima javnog informisanja i novinarstva. U toj jugoslovenskoj akciji naročito energičnim pokazalo se novoizabrano rukovodstvo Gradskog komiteta SK Beograda sa Slobodanom Miloševićem na čelu, koje 'nalaže komunistima NIRO Politika da definišu i ostvare program idejnopolitičkog delovanja u pogledu jedinstvene uređivačke politike i da svestrano analiziraju i ocene razloge i puteve pojavljivanja napisa nesocijalsitičke sadržine i nacionalističke intonacije i preduzmu mere protiv ovakvih pojava u NIN-u, Politici ekspres, TV Reviji, Intervju-u i Ilustrovanoj politici. To se odnosi i na slične pojave u Dugi, Novostima 8 i Saboru". ${ }^{32}$ Posledično, zavladala je specifična situacija u Srbiji, „gde su vodeći mediji (RTB i Politika) već nekoliko godina svedeni na nivo biltena vladajuće komunističke partije. “33 To nije nužno značilo da je sva štampa govorila jednim glasom, već da je postala sredstvo unutarpartijskih sukoba, koji su postajali sve oštriji, tako da su se nesuglasice koje su postojale unutar srpske komunističke partije itekako mogle iščitavati na stranicama beogradske štampe.

Alarmantni medijski skandali, poput pojave nacrta Memoranduma SANU u Večernjim novostima krajem septembra 1986. i sa njim povezanog objavljivanja humoreske Vojko i Savle u Politici januara 1987, ukazivali su na dramatičnu eroziju profesionalnih standarda, dok je slučaj omladinskog lista Student iz aprila iste godine ukazivao na odlučnost sistema da očuva kontrolu nad medijima. ${ }^{34}$

U politizaciji medijske sfere naročito prednjači Slobodan Milošević, tada već predsednik CK SKS. Odlučno guši bilo kakve pokušaje emancipacije novinara, koji za njega predstavljaju „pokušaj konstituisanja političke opozicione organizacije." Poziva na budnost na sednicama Gradskog komiteta, „naročito u izdavačkim i novinskim kućama i drugim institucijama

\footnotetext{
${ }^{31}$ M. Bjelica, $n$. d., 64-65.

${ }^{32}$ Cit. prema: M. Bjelica, $n$. d., 65-66.

${ }^{33}$ O. Pribićević, $n$. d., 67.
}

${ }^{34}$ Videti Miodrag Marović, „Politika“ i politika, Helsinški odbor za ljudska prava, Beograd 2003. O slučaju Student videti Dragomir Bondžić, Beogradski univerzitet i Osma sednica. Stanje na Univerzitetu 1987. godine i „slučaj Student", u: M. Pavlović, D. Jović, V. Petrović (prir.), n. d., 149-160. 
koje direktno utiču na stvaranje javnog mnjenja“. ${ }^{35}$ Upušta se u detalje kadrovske politike u medijima i istrajno radi na promociji svojih simpatizera u njima. ${ }^{36}$ Ova će se investicija ubrzo isplatiti, prilikom Miloševićeve posete Kosovu Polju krajem aprila 1987, tokom koje je otvoreno uzeo u zaštitu predstavnike kosovskih Srba. ${ }^{37}$ Ta poseta je označila početak nove medijske strategije. Njena prezentacija na beogradskoj televiziji promovisala je Miloševića u nacionalnog lidera. Njegova izjava demonstrantima ( "Niko ne sme da vas bije“) postaje medijska atrakcija. Tadašnji zamenik direktora RTB Dušan Mitević, kućni prijatelj Slobodana Miloševiće i njegove supruge Mirjane Marković, koji je stajao iza ove orkestracije, prisećao se: „Emitovali smo Miloševićevo obećanje na TV bez prekida. To ga je i lansiralo.“ Sećao se i Miloševićeve reakcije: „Mi smo taj izveštaj pravili za svoje redovne emisije, mi imamo tri kanala, i on je bio vrlo zadovoljan tim putem, zato što misli da je uradio ono što je trebalo da uradi. “38 Propagandna poruka pala je na plodno tle. Nižu se televizijski i novinski izveštaji o Miloševićevom susretu sa predstavnicima kosovskih Srba, koji štampa romantično naziva „najduža noć“. Najavljuje se novi, beskompromisan pravac čiji se začetnik čak i opeva: „Ali pristiže lep mladi govornik / Sunce koje zalazi pali mu nakostrešenu kosu / Razgovaraću sa svojim narodom i na ledini, kaže / U školskom dvorištu, na njivi“. ${ }^{39}$

Ovakav razvoj je u velikoj meri zatekao Miloševićevog dugogodišnjeg promotera, predsednika Predsedništva SR Srbije Ivana Stambolića. Stambolić je smatrao da nagla radikalizacija kosovskog pitanja ugrožava dotadašnje napore usmerene ka promeni odnosa između republike i pokrajina i da otvara vrata nacionalističkoj histeriji. Nije blagovremeno uvideo da je upravo to bilo sredstvo kojim je Milošević nastojao da ostvari cilj - njegovo uklanjanje i učvršćenje sopstvene vlasti u Srbiji. Dok je Stambolić uzaludno nastojao da izbegne konfrontaciju, partija i javnost su se ubrzano opredeljivali između „Ivice i Slobe“. Sa njima i mediji: „Bilo je specijalno zadovoljstvo pratiti to gambanje“, piše Slavko Ćuruvija: „Počelo je svrstava-

${ }^{35}$ Radilo se o pokušaju stvaranja novinarskog Fonda solidarnosti. - M. Bjelica, $n$. d., 79 .

${ }^{36}$ Tako Milošević na sednici Gradskog komiteta 18. februara 1987. kaže: „Promenjen je glavni urednik Duge, ali se stanje u Dugi neće promeniti dok ne dođe do promene u redakciji Duge u širem smislu. Razgovaramo i o novom glavnom uredniku NIN-a. Bez obzira na rešenje do koga dođemo, nećemo rešiti probleme u NIN-u ako ne dođe do ozbiljne rekonstrukcije čitave redakcije." Cit. prema: A. Nenadović, Politika u nacionalističkoj oluji, u: N. Popov, n. d., tom II, 169.

${ }^{37} \mathrm{O}$ ovoj poseti i usponu Slobodana Miloševića u: Kosta Nikolić, Niko ne sme da vas bije, Slobodan Milošević u Kosovu Polju 24-25. april 1987, Beograd 2006.

${ }^{38}$ Lora Silber, Alan Litl, Smrt Jugoslavije, Beograd 1996, 31.

${ }^{39}$ Radoslav Zlatanović, Himna na ledini, Književne novine, 38/1987, br. 731, 1. maj 1987. 
nje u suprotstavljene blokove. Miloševića odmah podržala Politika, sa Žikom Minovićem na čelu. Televizija, sa direktorom Erićem, tek se kasnije presaldumila u tom smeru." 40

U tako napetoj atmosferi okinut je oroz u kasarni u Paraćinu, u kojoj je 3. septembra vojnik albanske nacionalnosti Aziz Keljmendi u rastrojstvu pucao po spavaonici, usmrtio četiri druga regruta, a ranio petoricu. O načinu na koji je beogradska štampa propratila ovu tragediju piše tadašnji glavni i odgovorni urednik Politike Živorad Minović: „Kad danas o svemu tome mislim, mogućno je da smo u nečemu i grešili (...) podsećam kako je izgledala prva strana Politike 4. septembra 1987. godine. Prva dva stupca: 'Ubijena četiri vojnika', druga tri: „Keljmendi pucao u Jugoslaviju.“ Naslov 'Keljmendi je pucao u Jugoslaviju' dao je jedan od urednika Politike, jer su poginuli vojnici bili različitih nacionalnosti i iz različitih krajeva Jugoslavije. (...) Smatrali smo da zbog delikatnosti događaja jedino treba da se konsultujemo sa vrhom Jugoslovenske narodne armije. Rečeno nam je da o informacijama, izveštajima, komentarima i njihovim intonacijama treba da se dogovaramo sa Političkom upravom SSNO (...) ni taj vrh ni Milošević uopšte nisu imali nikakav kontakt sa Politikom. Povodom tog tragičnog događaja (...) smo jedine kontakte imali sa Političkom upravom SSNO i mislim da je bilo dobro što smo ih imali“. ${ }^{41}$

Bez obzira na to da li je iza antialbanskih intonacija u beogradskoj štampi stajala JNA ili Milošević, ona je objektivno išla na ruku Miloševićevoj struji, prikazujući Stambolića kao kompromisera nedoraslog dramatičnoj situaciji. Ivan Stambolić piše: „Posle ubistva vojnika u kasarni u Paraćinu nastaje kvalitativna promena $u$ javnom mnjenju Srbije. Posle svega, $u$ sredstvima javnog informisanja. Do Paraćina, Žika Minović i ostali uvažavali su ono što sam im govorio. A govorio sam im: 'Čekajte. Polako. Idemo već sa merama. Nemojte, ljudi, tu ljutu travu na ljutu ranu.' Posle Paraćina, i Slobodan Jovanović i Žika Minović i Dušan Mitević počinju otvoreno da mi se suprotstavljaju, da se raspravljaju sa mnom, da odbijaju ono na čemu insistiram (...) U Politici je nacionalistička provala posle Paraćina. Kao po komandi. Počinju da pale Srbiju. Dižu Srbe na noge. Da je Milošević godinama planirao šta bi valjalo preduzeti da dođe do šanse, ne bi mogao smisliti povoljniji događaj." 42

U dogovoru sa Ivanom Stambolićem, situaciju je nastojao da smiri sekretar Gradskog komiteta Dragiša Pavlović. Slavko Ćuruvija o tome piše: „Tog leta je došlo do ubistva vojnika u Paraćinu, što je kasnije iskonstruisa-

\footnotetext{
${ }^{40}$ P. Popović, $n$. d., 174.

41 Živorad Minović, Ulični biograf. Knjigom na knjige Slavoljuba Đukića, Beograd 2010, 104-107.

${ }^{42}$ Žrtve. Ivan Stambolić Slavku Ćuruviji, Beograd 2006, 30.
} 
no u uvod u konačni obračun za vlast u Srbiji. Žika Minović je tu tragediju digao na planetarni nivo, žestoko potpalio, pa se Dragiša Buca Pavlović istrčao, verovatno u dogovoru sa Stambolićem, da gasi vatru. Sazvao sastanak sa glavnim i odgovornim urednicima beogradskih medija, pa u kritici nacionalističke opcije izgovorio sintagmu 'olako obećana brzina', koja je kasnije prerasla u liniju blokovske diferencije." ${ }^{43}$ Pavlović je na tom sastanku, koji je javno prenošen 11. septembra, upozoravao: „Situacija u Kosovu, koja se ne poboljšava željenom i obećanom brzinom stvara opasnu atmosferu, gde svaka reč izgovorena protiv srpskog nacionalizma je shvaćena kao nacionalizam. Strastvene reči mogu doneti samo vatru (...) Šta treba da se dogodi da bismo shvatili da obarač na oružju povlače i neodmerene reči na javnoj sceni?"44 Izvršni sekretar gradskog komiteta Radmilo Kljajić ilustrovao je ove pojave primerima iz Politike, Politike Ekspres i Intervjua. Iako su njihovi prekori bili upućeni predstavnicima medija, mogli su se čitati i kao optužba na račun političara koji nude sumnjive prečice, odnosno olako obećavaju brzinu.

Ispostavilo se da je ovaj pokušaj predstavljao uvod u dotada najozbiljniju političku krizu, budući da Milošević nije imao nameru da ustukne. Po Slavoljubu Đukiću, 13. septembra 1987, „u kući Mirjaninog dede, gde Miloševići provode slobodne dane, sastaju se Slobodan, Mira Marković, Dušan Mitević i glavni urednici Politike i Ekspresa, Živorad Minović i Slobodan Jovanović. Tu je dogovoreno da štampa počne kampanju protiv Dragiše Pavlovića. Tekst je napisala Mira Marković, a ispomagao je Živorad Minović, glavni urednik Politike, koji je imao i ulogu daktilografa. Dogovoreno je da komentar publikuje Ekspres i da ga prenese uticajna Politika čime će se javnosti dati do znanja o ozbiljnosti događaja. Ostalo je samo jedno, tehničko pitanje: ko da potpiše komentar? Potpisao ga je novinar Ekspresa Dragoljub Milanović, koji nije učestvovao na sastanku u Požarevcu. "45 Slavko Ćuruvija dodaje neznatno drugačiju verziju: „Pošto to nije znao sam da napiše, čuveni Dragoljub Milanović, s Kosovo i s brkovi, mali zarozani provincijalac, seo je i potpisao komentarčinu u kojem je rasturan Buca Pavlović. To je verovatno napisao ili Žika Minović ili Slobodan Milošević. “46 Kako

${ }^{43}$ P. Popović, n. d., 175.

${ }^{44}$ Dragiša Pavlović, Olako obećana brzina, Zagreb 1988, 97-98.

${ }^{45}$ S. Đukić, n. d., 238-239.

${ }^{46}$ P. Popović, $n$. d., 176. - Živorad Minović poriče Đukićeve tvrdnje da je učestvovao u pripremi ovog medijskog puča: „Mogao sam o nemu misliti bilo šta, ali ni u snu nisam pomišljao da bi mogao biti toliki klevetnik. (...) Nisu bili prisutni samo ljudi koje pominje Đukić. Bilo je još nekoliko, kako on, korčaginovski kaže, učesnika ovog kružoka... ali te druge ličnosti, ne znam iz kojih razloga, on ne pominje. A bilo bi i više nego indikativno i značajno da ih je pomenuo. (...) Ništa u Požarevcu nije "dogovoreno" u vezi sa „reagovanjem“ Ekspresa povodom istupanja Dragiše Pavlovića. Glavni urednik Ekspresa Slobodan Jovanović, 
bilo, posle objavljivanja "Milanovićevog“ komentara Olake ocene Dragiše Pavlovića, objavljenog u Politici Ekspres, zakazuje se sednica Predsedništva CK SKS. Na njoj se po Miloševićevom zahtevu razmatra slučaj Dragiše Pavlovića. Uprkos Stambolićevom protivljenju, tesnom većinom usvaja se odluka da se Radmilo Kljajić isključi iz Saveza komunista, a Pavlović iz partijskog Predsedništva i da se preispita odgovornost njemu bliskih ljudi u medijskoj sferi (Ivana Stojanovića, Momčila Baljka). Da ritualno potvrdi ove odluke, saziva se Centralni komitet, na čuvenoj Osmoj sednici koja je održana 23. i 24. septembra $1987 .{ }^{47}$ Razrešenjem Dragiše Pavlovića iz partijskog rukovodstva na sednici koja je bila televizijski prenošena oslabljena je i pozicija Stambolića, čiju aktivnost i liderske ambicije tokom sednice kritikuju Miloševićeve pristalice. Napadan sve žešće i u vodećim srpskim glasilima, Ivan Stambolić do kraja godine podnosi ostavku. „Dva meseca su po novinama i televiziji raspisivali poternice za ljudima, proganjali ih, obešćašćivali, smenjivali (...) Mene su ostavili za kraj. Metod je isti. Krenuli su sa nekim paušalnim, neodređenim optužbama. Osnovna kvalifikacija je, prvo, oportunista, pa onda i izdajnik srpskog naroda. (...) Stvarala se atmosfera progona. Bespomoćan si. Ne možeš javno ništa. “48

Nakon Osme sednice, iz medijske sfere velikom brzinom se uklanjaju ne samo Stamboliću odani kadrovi, već i novinari od integriteta i stava. Sa RTB-a odlazi urednik Informativno-političkog programa Mihailo Erić, a Gordana Suša je sklonjena sa ZIP-a. U Svetu Jelenu Jevremović zamenjuje Ljiljana Bulatović. Ostavke podnose glavni urednici NIN-a (Mirko Đekić) i Duge (Grujica Spasović) a na njihova mesta dolaze Đoko Stojčić i Ilija Rapa-

s kojim sam putovao u Požarevac, gotovo uzgredno mi je rekao da su napisali komentar povodom izjave D. Pavlovića, koji će 'u sutrašnjem broju', u ponedeljak 14. septembra, Ekspres objaviti na drugoj, komentatorskoj strani. Napomenuto mi je da se sadržaj zasniva na njegovoj polemici sa Pavlovićem na sastanku sa glavnim urednicima dan pre toga u Gradskom komitetu. (...) A što se tiče Mire Marković, ona tada nije ništa ni diktirala ni pisala, već nam je kuvala kafu. (...) Pokušaću da mu odgovorim kratko. Taj susret u Požarevcu smo S. Jovanović i ja u šali nazivali šifrovanim imenom „Lubenica“, jer je nas nekolicinu iz Beograda i nekoliko ljudi iz Požarevca te nedelje Milošević pozvao „na bostan“. Dan je protekao u neobaveznom ćaskanju u kojem Mirjana nije učestvovala, osim u već pomenutoj ulozi kafekuvarice. Kasnije sam obavešten da je Dušan Mitević ispričao Đukiću svoju verziju tog susreta, a ovaj ju je prihvatio kao takvu, dakle netačnu ... Vara se Đukić kad misli da je u pomenutom „kružoku“ u Požarevcu bilo odanih i poverljivih ljudi. U tom sunčanom septembarskom danu, oko velikog stola sa crvenim kriškama lubenice, niko nikom nije bio odan, niko nikome nije verovao, svako je merio šta će da kaže i niko nije znao šta je u Miloševićevoj glavi ... Požarevački susret Sl. Đ. (na osnovu Mitevićevih priča) ocenio je kao zaveru od koje je maltene sve počelo, a ja ga opisujem zbog besprimernih kleveta koje mi je u tekstu o tome on naneo". - Ž. Minović, Ulični biograf, 112-115.

${ }^{47}$ Osma sednica CK SKS, Beograd 1987. Up. M. Pavlović, D. Jović, V. Petrović (prir.), Slobodan Milošević: Put ka vlasti. Osma sednica CK SKS, Beograd 2008.

${ }^{48}$ Ivan Stambolić Slavku Ćuruviji, Žrtve, Beograd 2006, 89-90 
jić. ${ }^{49}$ Atmosferu čistke opisuje Mirko Đekić: „Krenule su partijske komisije, sastavljene od istaknutih partijskih aktivista, sastanci, ispitivanja. U komisiji koja je formirana da se ispita politička odgovornost ne samo Mirka Đekića, već i većeg dela redakcije, bilo je nekoliko članova iz Slobinog jurišnog odreda. U komisiji su bila po dva predstavnika Predsedništva CK Srbije, Gradskog komiteta, Komisije za informisanje i Opštinskog komiteta Stari Grad. Glavnu reč u Komisiji vodio je Zoran Todorović Kundak." ${ }^{50}$

Dok se upražnjena mesta popunjavaju Miloševićevim pristalicama, njegovi najbliži saradnici zadržavaju pozicije ili avanzuju u ključnim republičkim medijima. Dušan Mitević prelazi na čelo RTB, a Slobodan Jovanović ostaje glavni urednik Politike Ekspres, u kojem promoviše novinare koji se eksponiraju senzacionalističkim i nacionalističkim tekstovima - Ljiljanu Bulatović, Dragoljuba Milanovića, Miroslava Markovića. ${ }^{51}$ U Politici, glavni i odgovorni urednik Živorad Minović se oslobađa predsednice Izdavačkog saveta Živane Olbine i „Ivana Stojanovića, direktora Politike i člana CK SK Jugoslavije, koji je iz novina saznao da je Predsedništvo CK SK Srbije zaključilo da predloži Socijalističkom savezu Srbije da on bude smenjen sa dužnosti direktora Politike." "52 Umesto Stojanovića, v. d. direktora od 12. oktobra 1987. postaje sam Minović, koga Predsedništvo republičke konferencije SSRN Srbije ustoličava za direktora 25. decembra, budući da „svojim idejno-političkim opredeljenjem i dokazanom stručnim i drugim sposobnostima pruža uverenje da će uspešno obavljati dužnosti direktora NO Politika (...)

U jednom politički složenom razdoblju, kada je na Politiku vršen pritisak van kuće i u samoj Kući da se odstupi od društveno utvrđene uređivačke politike, redakcija i glavni urednik Minović uspeli su da osnovna orijentacija lista ostane na liniji Saveza komunista“, obrazlagalo je odluku ovo telo. ${ }^{53}$

Držeći istovremeno funkcije direktora i glavnog i odgovornog urednika, Minović postaje ključni branilac tekovina Osme sednice. Ne propušta nijednu priliku da istakne svoje „provoboračke“ zasluge. Na sastanku

${ }^{49}$ M. Bjelica, $n$. d., 68.

${ }^{50}$ Miloš Mišović, Naslednici bez testamenta, Razgovori sa glavnim urednicima NIN-a, Beograd 1999, 199.

${ }^{51}$ Upitan da li ima utisak da je njegovo glasilo prednjačilo u napadima na Miloševićeve protivnike, Jovanović je rekao: „Ekspres jeste bio perjanica, ali ne u tom smislu. List je imao veliki tiraž i značajnu poziciju koja se ne može nametnuti nikakvim veštačkim ili dirigovanim sredstvima, nego je bio prihvaćen od čitalaca. Bilo je oštre reči, bilo je izrazitih, jakih tekstova i komentara, bilo je mnogih otkrića koje niko drugi ni po nedelju dana kasnije nije smeo da preuzme." - Slobodan Jovanović, Virtuelna Srbija, Beograd 2000, 121-122.

${ }^{52}$ M. Marković, $n$. d., 19.

${ }^{53}$ Politika za nas, 29. decembar 1987, br. 33, str. 1. 
Komisije za novinare Gradskog komiteta CK SKS, posvećenom ovim promenama, dok se čelni ljudi medijske sfere nadmeću u žestini (Slobodan Jovanović, Aleksandar Prlja, Ljiljana Bulatović, Sergej Šestakov, Dušan Mitević, Bora Ilić, Momir Brkić), Minović komentariše pisanje zagrebačkog lista Danas o ovom događaju: „Prosto ne mogu da verujem da taj list dovodi u pitanje Osmu sednicu CK Srbije na taj način što postavlja pitanje da li je ta sednica na Titovom putu. Ja težu optužbu nisam pročitao“. ${ }^{54} \mathrm{Na}$ istom tragu, partijski kolektiv Politike neposredno po Osmoj sednici drži sastanak na kojoj se njen ishod kuje u zvezde. Podnosilac izveštaja na Konferenciji SK NO Politika, Ljijana Bulatović zaključuje: „Osma sednica CK SK Srbije (...) afirmisala je značaj javnosti i demokratičnosti u političkom radu“. Živorad Minović je takođe pozdravio rezultate sednice, hvaleći se da je i u ovim okolnostima „Politika odolela pritiscima i manipulacijama“. Najdalje je otišao Slobodan Jovanović: „Što se tiče Osme sednice, pre i posle i povodom nje, kada ovde govorimo, dozvoliću sebi da kažem da je ovo samo priprema za neku vrstu 'naše Osme sednice' (...) Ako ima otpora, onda da se diferenciramo. "55

Tokom druge polovine 1987. i 1988. godine iz ključnih srpskih medija odlaze ili se isteruju najbolji novinari ${ }^{56} \mathrm{Ni}$ profesionalizam ni tiraži, međutim, nisu bili bitni novoj uređivačkoj ekipi, već lojalnost novom lideru i jasno usmerenje ka konsolidaciji njegove moći. Ujednačavanje medijskog prostora posle Osme sednice i simbolično je zapečaćeno glamuroznom proslavom 84. rođendana Politike 23. januara 1988. u Domu JNA, kojoj je prisustvovalo čitavo srpsko državno i partijsko rukovodstvo.

Okružen generalima Petrom Gračaninom, predsednikom Predsedništva Srbije i članom Predsedništva SFRJ Nikolom Ljubičićem, Dušanom Čkrebićem, članom Predsedništva CK SKJ, Bogdanom Trifunovićem, predsednikom Predsedništva konferencije SSRNS, Aleksandrom Bakočevićem, predsednikom Skupštine grada Radošem Smiljkovićem, Predsednikom GK SK Beograda, kolektivu Politike je na uspesima u dosadašnjem radu čestitao predsednik Predsedništva CKSKS i najmoćniji čovek u Srbiji - Slobodan Milošević. ${ }^{57}$

\footnotetext{
${ }^{54}$ M. Bjelica, $n$. d., 68.

${ }^{55}$ Sa sednice konferencije SK NO Politika: „Velika je snaga Osme sednice“, 29. decembar 1987, Politika za nas, 5-9.

${ }^{56}$ Tako je Aleksandar Nenadović napadnut člankom u Politici Ekspres, koji su potpisali Slobodan Jovanović i Dragoljub Milanović. „Uzalud sam tražio odgovor na logično pitanje; da li će glavni urednik mog lista, koji je kao direktor cele firme nadređen i urednicima Ekspresa, uzeti u zaštitu svog dopisnika iz SAD ili će me redakcija opozvati, ako neće smeti neće da me brani? Žika je zagonetno ćutao“. - A. Nenadović, $n$. d., 281.

${ }^{57}$ Politika za nas, 27. januar 1988, 1-3, br. 334.
} 


\section{Novi pravac - od vlasti do režima}

Mediji nisu doveli Slobodana Miloševića na vlast, a ni javnost u širem smislu reči nije doprinela njegovoj pobedi. On se uspinjao postepeno lestvicama partijske nomenklature, putem koji mu je krčio Ivan Stambolić. $\mathrm{Na}$ tom putu, Milošević je umeo da prepozna važnost kontrole nad sredstvima informisanja, koja su odsudno doprinela nadigravanju svog mentora. Našavši se na čelnoj poziciji, bez konkurenta u redovima srpskih komunista, nastojao je da održi i opravda stečeni monopol forsiranjem političke misije - rešenja srpskog državnog pitanja. Medijska sfera je tako postala ključno oruđe konsolidacije njegove vlasti i njenog prerastanja u režim. „Umesto ka pluralizaciji medijskog sistema, napori vlasti bili su usmereni ka održavanju vladajućeg državno-partijskog modela medija i nastojanju da se osigura funkcionisanje medija kao glavnog instrumenta u osnaživanju nove nacionalističke ideologije i vladajuće partije kao njenog ekskluzivnog protagoniste", piše Jovanka Matić. ${ }^{58}$ Disciplinovano novinarstvo upustilo se u koordiniranu medijsku ofanzivu koja je pratila Miloševićevu borbu za slamanje pokrajinskih autonomija. Medijska taktika bila je jednostavna i efikasna. Mitinge podrške ovom kursu, koji se od leta 1988. kapilarno i organizovano šire centralnom Srbijom, beogradska televizija prenosi i prezentuje kao izraz „antibirokratske revolucije“, ali i plebiscitarne podrške rukovodstvu koje je personifikovao Milošević. ${ }^{59}$ Rapidni potezi kojima je destabilizovano rukovodstvo Vojvodine i Kosova, a zatim i Crne Gore, prezentovani kao izjašnjavanje volje srpskog naroda, štaviše kao njegovog „događanja“, kako se na jednom od mitinga izrazio književnik Milorad Vitezović, a televizija ponavljala u beskraj.

Štampani mediji su takođe dali velik doprinos stvaranju ovakve atmosfere, a pre svega Politikina grupa. Samom listu Politika je zahvaljujući tradicionalnom ugledu namenjena specifična uloga. Milošević dolazi u radnu posetu rukovodstvu grupe 5. jula 1988, nakon kojeg je „povoljno ocenio nastojanje NO Politika da se razvija na savremenim tehničko-tehnološkim, informativnim i ekonomskim osnovama". ${ }^{60}$ Tri dana kasnije, list otvara svoje stranice za novu rubriku, nazvanu „Odjeci i reagovanja“, koja je pod krinkom liberalizacije štampe i otvaranja prema čitaocima služila kao poligon za osudu režimskih protivnika i najavu političkih čistki naručenim tekstovi-

58 Jovanka Matić, Televizija protiv birača. Televizijska kampanja za parlamentarne izbore u Srbiji 1990-2000, Beograd 2007, 60.

${ }^{59}$ Bojan Lekić, Zoran Pavić, Slaviša Lekić (prir.), Kako se događao narod: Antibirokratska revolucija, Beograd 2009; Nebojša Vladisavljević, Serbia's Antibureaucratic Revolution: Milosevic, the Fall of Communism and Nationalist Mobilization, Palgrave, London 2008.

${ }^{60}$ Politika za nas, 3. avgust 1988, 340, str. 3-5. 
ma. ${ }^{61}$ „Zamišljena, očigledno, kao kanal za podsticanje i usmeravanje vaniinstitucionalnog rešavanja političkih problema, rubrika se prvi put javlja 8. jula 1988. godine, na sam dan održavanja mitinga Srba i Crnogoraca sa Kosova u Novom Sadu, kojim je otvorena duga i vruća sezona „događanja naroda. “62 Masovni protesti koji se tokom jeseni gusto koncentrišu u Vojvodini dovode 6. oktobra 1988. do odstupanja vojvođanskog rukovodstva i njegove smene Miloševićevim sledbenicima. ${ }^{63}$ Sličan scenario uspeva i u Crnoj Gori početkom 1989. U istom periodu, otpori Miloševićevoj politici na Kosovu se slamaju silom, a obe se pokrajine krote ustavnim amandmanima koje Skupština SR Srbije ceremonijalno proglašava 28. marta $1989 .{ }^{64}$ Ritam ovih promena na karakterističan način odražava štampa. Naslovnice $N I N-a$ iz istog perioda donose faksimil Zakona o zabrani povratka Srba na Kosovo, tekst „Dva nataliteta" uz sliku albanske porodice sa sedamnaestoro dece i osnovne škole sa jednim učenikom Srbinom, fotografiju kosovskih Srba i Crnogoraca sa demonstracija u Novom Sadu, fotografiju iz sela Prekale na kojoj Srpkinja sa puškom o ramenu čuva decu na njivi, te tekst pod naslovom „Sto dana koju su potresli Crnu Goru“. Ova kaskada se trijumfalno završava naslovnicom „28. III 1989. Srbija - Republika! Proglašenje ustava Srbije". 65

Sa preuzimanjem kontrole nad pokrajinama, širi se i medijska baza Miloševićeve moći. U Vojvodini se u sprovođenju čistki u novinarskoj organizaciji naročito istakao Mihalj Kertes, Miloševićev čovek od poverenja i novi član Predsedništva SR Srbije. Na vanrednoj skupštini Društva novinara Srbije, održanoj u Vrbasu krajem maja 1989, kojoj je prisustvovao Kertes, zatražena je „oštra diferencijacija u RTV Novi Sad, što je bio siguran znak da se pripremaju nove čistke (...) U svom prepoznatljivom stilu Mihalj Kertes izjavio je da treba odmah oduzeti pero 'onima koji su bili u službi stare politike'." ${ }^{“ 66}$ Još se oštrije postupa na Kosovu. Početkom jula 1990. Skupština Srbije donosi odluku o prestanku rada Skupštine Kosova i Pokrajinskog izvršnog veća, a istovremeno se uvode privremene mere u RTV Priština i u Rilindiji. Smenjuje se rukovodstvo, bez posla ostaje 1500 ljudi

${ }^{61}$ Reprezentativan deo priloga iz ove rubrike objavljen je u: Aljoša Mimica, Radina Vučetić, Vreme kada je narod govorio. Odjeci i reagovanja u Politici, 1988-1991, Beograd 2008. Videti i Jelka Jovanović, Bojan Tončić (prir.), „Vreme kad je narod govorio“. Odjeci i reagovanja (Politika, 1988-1991). Okrugli sto, 14-15. decembar 2001, Beograd 2002.

${ }^{62}$ A. Mimica, n.d., 24.

${ }^{63} \mathrm{O}$ toku ,antibirokratske revolucije“ u Vojvodini i ustavnim promenama videti Kosta Nikolić, 'Ili će Srbija biti republika, ili će prestati da postoji!' - ustavne promene u Srbiji 1989 (I), Istorija 20. veka, 2012/2, 165-188.

${ }^{64} \mathrm{O}$ donošenju Ustava videti Kosta Nikolić, 'Ne damo Kosovo' - ustavne promene $u$ Srbiji (II), Istorija 20. veka, 2012/3, 171-90.

${ }^{65}$ M. Mišović, n. d., 216-217.

${ }^{66}$ M. Bjelica, n. d., 87. 
zaposlenih u ovim sistemima, a zatvara se i šest lokalnih radio stanica koje su emitovale program na albanskom jeziku. I u Beogradu se guše poslednji džepovi otpora. Sa televizije su smenjeni Goran Milić, Mihailo Kovač i Omer Karabeg, a Radnički savet NIP Politika prepolovljava platu četrdesetorici novinara koji su pristupili Udruženju nezavisnih novinara Srbije. ${ }^{67}$ Srpski državni mediji počinju borbu protiv glasila poput Borbe, televizije Yutel ili novoosnovanog nedeljnika Vreme, koji ne aplaudiraju Miloševićevoj politici konfrontacije.

Sa druge strane, pljušte nagrade za lojalne medijske čelnike. Slobodan Jovanović prima Oktobarsku nagradu za seriju svojih tekstova o aktuelnim zbivanjima u Srbiji, Kosovu i Jugoslaviji, kao i godišnju nagradu NO Politike za izuzetne uređivačke poteze. Predsedništvo RK SSRN Srbije ga glatko reizabira na mesto glavnog i odgovornog urednika Ekspresa, kao čoveka „pod čijim je rukovodstvom Ekspres postao glasilo progresivne orijentacije i istinska demokratska tribina. Veliki je Jovanovićev doprinos što se $\mathrm{u}$ ovom periodu nalazio $\mathrm{u}$ samom špicu borbe na kursu Osme sednice CK SK Srbije.“68 Živorad Minović je 31. januara 1990. takođe ponovo imenovan na obe svoje funkcije - direktora NIP Politika i glavnog i odgovornog urednika lista Politika. ${ }^{69}$ Nije zanemarena ni televizija. Tri najveća televizijska sistema u SR Srbiji (Beograd, Novi Sad i Priština) objedinjavaju se, i pod nadzorom Miloševićevog intimusa Dušana Mitevića otpočinju transformaciju ka Radio-televiziji Srbije. U pročelju ove transformacije nalaze se Sergej Šestakov, Milorad Komrakov i drugi. Slična je situacija i u manje uticajnim glasilima, koja se prilagođavaju novom kursu. Kako piše Vidosav Stefanović, „bitka za medije počinje uklanjanjem glavnih urednika i novinara koji oklevaju da se izjasne. Na njihovim mestima pojavljuju se manje poznati i manje kompetentni novinari, ali spremni da sprovedu ono što im se naredi. Nijedna redakcija u Beogradu nije pošteđena, nijedno uredničko mesto. Putevi vode prema porodičnoj vili na Dedinju, naredbe otuda dolaze. Prijatelj porodice postaje direktor radio televizije Srbije (....) A televizija, vođena tvrdom rukom tog debeljka sa licem uvređenog dečaka, proizvodi ono što je potrebno porodici i većini koja je sledi: paralelnu stvarnost. Nije bitno ono što se događa već ono što se vidi na televiziji. Biće to „posao za perače mozgova“. Veština stečena u titoizmu biće primenjena u postkomunizmu. “70

${ }^{67}$ Isto, 72; M. Marović, n. d., 232.

${ }^{68}$ Politika za nas, 19. januar 1990, 358, 2

${ }^{69} \mathrm{O}$ tempu promena u Politikinoj grupi videti Živorad Minović, Dan počinje s Politikom: prilozi za proučavanje odnosa štampe i političke vlasti, Čačak 2008.

${ }^{70}$ Vidosav Stevanović, Milošević, jedan epitaf, Beograd 2002, 60-61. 
I zaista, dok u drugoj polovini 1989 komunistički režimi Istočne Evrope padaju jedan za drugim, i dok se Savez komunista Jugoslavije ubrzano rastače, Miloševićeve pozicije u Srbiji jačaju. U njoj se umesto rušenja komunizma eksperimentiše sa „pluralizacijom političkog sistema na socijalističkim osnovama" kroz 'razigravanje' partijske društvene transmisije, Socijalističkog saveza radnog naroda Srbije U praksi je to značilo raspisivanje izbora za predsednika Predsedništva SR Srbije novembra 1989, na kojima su se za ovu poziciju sa Miloševićem nadmetale njegove stranačke kolege, Mihalj Kertes, Zoran Pjanić i Miroslav Đorđević. Očekivano, Milošević trijumfuje sa $80,4 \%$ glasova od $67,1 \%$ izašlih birača. ${ }^{71}$ Savez komunista Srbije broji 820.000 članova, a njegovo rukovodstvo i ne pomišlja na odlazak sa vlasti, već sve bezobzirnije nastupa na jugoslovenskoj sceni, otvarajući pitanje transformacije federacije i partije. Savez komunista Jugoslavije pod teretom Miloševićevih centralizatorskih ambicija i definitivno puca 22. januara 1990. na 14. vanrednom kongresu. Međutim, ni raspad SKJ, kao ni rasap saveznih državnih institucija, ne ugrožava Miloševićev položaj. „Dezintegracija savezne zajednice, praćena jačanjem državnih atributa $u$ jugoslovenskim republikama, zaustavila je proces decentralizacije i oslobađanja medija od kontrole vlasti. Sa zaoštravanjem konflikata između republičkih centara moći, došlo je do pojačane centralizacije unutar republičkih medijskih podsistema, do smanjenja već osvojenih prostora profesionalne slobode i stavljanja medija u direktnu službu republičkih i pokrajinskih nacionalnih birokratija. ${ }^{\text {"72 }}$

Tek se sada vide razmere Miloševićeve početne prednosti stečene stezanjem medijskog obruča. Zakonom o informisanju SR Srbije iz 1989. omogućeno je osnivanje privatnih medija, ali ta mogućnost nije značajno ugrozila režimski monopol u medijskoj sferi. Naoko, medijska slika Srbije nikada nije bila šarenija. „Prema zvaničnim statističkim podacima, u Srbiji je 1990. godine izlazilo 1.447 listova i časopisa sa ukupnim godišnjim tiražom od 586 miliona primeraka. Najveći deo tiraža otpadao je na dnevne listove (357 miliona). Ukupno je izlazilo 14 dnevnih listova od kojih su devet informativno-politički (u Beogradu Politika, Politika ekspres, Borba i Večernje novosti, u Novom Sadu Dnevnik i Magyr szo, u Prištini Jedinstvo i Rilindija, u Nišu Narodni list). Najveći prosečni tiraž imale su Večernje novosti (222.000), Politika ekspres (199.000) i Politika (185.000), na četvrtom mestu bila je Borba (31.000). Radio i televizijske stanice delile su se na matične (republičke i pokrajinske) i lokalne. Statistika je 1990. registrovala 58 radio stanica u Srbiji (1.821.000 pretplatnika) i pet televizijskih stanica

\footnotetext{
${ }^{71}$ Isto, 73-4.

${ }^{72}$ J. Matić, n. d., 57.
} 
(1.620.000 pretplatnika).“73 Ovo šarenilo, međutim, vara. Mediji u društvenom vlasništvu ostali su pod kontrolom SSRN, a posle njegovog ukidanja status osnivača su preuzele republička, odnosno pokrajinske i opštinske skupštine, čime je još više ogoljena njihova veza sa vladajućom partijom. Nova glasila ne predstavljaju „nikakvu alternativu državnoj televiziji, sa TV centrima u Beogradu, Novom Sadu i Prištini. TV Beograd, prvi i najveći TV centar u Jugoslaviji, pokrivao je celokupnu teritoriju Srbije, tehnički bio odlično opremljen, raspolagao je ogromnim sredstvima od obavezne pretplate i imao brojan i iskusan profesionalni kadar. Od svih TV programa $u$ Srbiji, najveću gledanost imala je centralna večernja informativna emisija TV Beograd 'Dnevnik 2'."74 Ovu emisiju tokom 1990. prati svakodnevno više od tri miliona gledalaca, od kojih po istraživanjima $30 \%$ veruje u potpunosti u ono što čuje, $46 \%$ ponekad preispituje a samo $12 \%$ sumnja u sadržaj programa koji postaje uporišna tačka režima. ${ }^{75}$

Uspešan eksperiment sa pseudodemokratizacijom medijskog sektora proširuje se na čitav sistem. Savez komunista Srbije na svom XI kongresu u decembru 1989. obznanjuje da neće stajati na putu razvoju drugih partija. To u Srbiji ipak ide sporije no bilo gde u Jugoslaviji, a napetosti koje prate izbore u ostatku zemlje omogućavaju Miloševiću da otvori pitanje položaja srpskog naroda u drugim jugoslovenskim republikama i da istupa kao zaštitnik svih Srba u Jugoslaviji. U samoj Srbiji se sredinom 1990. pristupa dugo odlaganoj legalizacija političkih stranaka, ali se višestranačje od početka obesmišljava. Opoziciji se uskraćuje medijski prostor, a kada se sredinom juna 1990. tim povodom organizuje demonstracije, policija reaguje batinanjem ispred same zgrade televizije. Zgrada postaje istinski bastion režima, odnosno TV Bastilja, kako joj je „tepao“ opozicioni lider Vuk Drašković. ${ }^{76}$ Sa nje se građani Srbije početkom jula 1990. pozivaju da referendumskim izjašnjavanjem potvrde Miloševićevu odluku o odlaganju održavanja višestranačkih izbora do donošenja novog Ustava. Ovaj manevar omogućava režimu ne samo da se prestroji, već i predstavi delom, pa i predvodnikom reformskog procesa simbolisanog padom Berlinskog zida. ${ }^{77} \mathrm{U}$ tom duhu sredinom jula proglašava se ujedinjenje Saveza komunista Srbije i Socijalističkog saveza radnog naroda Srbije u "novu“ političku stranku Socijalističku partiju Srbije, koja nasleđuje sredstva, infrastrukturu i kadro-

${ }^{73}$ M. Bjelica, $n$. d., 94-5.

${ }^{74}$ J. Matić, n. d., 63.

${ }^{75}$ Slobodan Antonić, Zarobljena zemlja. Srbija za vlade Slobodana Miloševića, Beo$\operatorname{grad} 2002,105$.

${ }^{76}$ Isto, 98-99.

${ }^{77}$ Ivan Čolović, Sve je počelo u Srbiji? u: Ivan Čolović (prir.), Zid je mrtav, živeli zidovi, XX vek, Beograd 2009, 10-42. Preuzeto sa http://pescanik. net/2009/10/sve-je-pocelou-srbiji/ 
ve ovih organizacija. Za predsednika SPS-a se bira Slobodan Milošević. Novi Ustav, donet 28. septembra, krojen je po njegovoj meri, predviđa široka predsednička ovlašćenja. Izborni zakon je jednako povoljno smišljen, predviđa većinski sistem koji ide na ruku najjačoj partiji. Ostaje još da se dobiju izbori, u dva decembarska izborna ciklusa.

Tok prve predizborne kampanje umnogome je isplatio Miloševićevo investiranje $\mathrm{u}$ nadzor nad medijskim sistemom. Formalno, svim partijama koje su se nadmetale na izborima prepušten je podjednak medijski promotivni prostor u za to specijalno oformljenim emisijama poput Izborne hroni$k e$. To međutim dovodi do haotične prezentacije programa desetak izglednih opozicionih stranaka i tridesetak marginalnih, pa i za tu priliku od režima osnovanih pseudostranaka. Zbunjujuću kakofoniju izborne ponude natkriljuje vladajuća stranka, čiji se kandidati otvoreno favorizuju u udarnim informativnim emisijama i predstavljaju kao stubovi ekonomskog prosperiteta, ali pre svega stabilnosti poretka. Pri tom, najtiražnija štampa takođe radi na diskreditaciji opozicije, dok najgledanija televizijska informativna emisija Dnevnik 2 i radijske vesti stavljaju svoju minutažu u službu kandidata režima, a pre svega Slobodana Miloševića, koji je samo tokom predizborne sedmice pominjan ravno 133 puta u prilozima ukupnog trajanja od 37 minuta. ${ }^{78}$ Isticanje njegove državničke uloge u savršenom je skladu sa izbornim sloganom Socijalističke partije Srbije - „Sa nama nema neizvesnosti!".

U rastućoj atmosferi nebezbednosti koja je pratila rastakanje SFRJ tokom druge polovine 1990. godine, ova poruka pada na plodno tle. $\mathrm{Na}$ izbore, održane 9. i 22. decembra, građani izlaze masovno, čak 71,5\% od upisanih u birački spisak. Socijalističkoj partiji Srbije poverenje poklanja 46,1\% izašlih birača. Zahvaljujući izbornom sistemu, Miloševićeva stranka zadobija 194 od 250 poslaničkih mesta u Narodnoj skupštini Srbije, i tako postaje jedna od retkih postkomunističkih partija koja opstaje na vlasti posle pada Berlinskog zida. Ovaj uspeh međutim ostaje u senci trijumfa samog Slobodana Miloševića, koji se za mesto predsednika Srbije nadmetao sa još 31 kandidatom. Za njega je glasalo gotovo dve trećine, 65,35\% izašlih birača. U odsustvu efektivnih mehanizama kontrole, teško je reći u kojoj su meri rezultati proizvod izborne krađe, a u kojoj medijske manipulacije. ${ }^{79}$ Opozicija uzalud ističe dugu listu zloupotreba tokom izbornog procesa. Slobodan Milošević (p)ostaje predsednik Srbije. Pobednik se u izjavi beogradskoj televiziji osvrće i na medijsku scenu: „Očekujem da, posle ovih izbora,

\footnotetext{
${ }^{78}$ S. Antonić, $n$. d., 107. Televizijska prezentacija izbora analizirana je u J. Matić, $n$. d., 64-87.

${ }^{79}$ Izborna regulativa i rezultati u Vladimir Goati, Izbori u SRJ od 1990. do 1998: volja građana ili izborna manipulacija, Beograd 1999, 4-25.
} 
sa televizije, radija i iz štampe konačno nestanu međusobne optužbe i mržnja, a sa trgova i ulica da se počiste pocepani plakati, da narod odahne i da svako, svojim radom, pomogne sopstvenom napretku, napretku svoje porodice i svoje republike, napretku Jugoslavije, naše zajedničke domovine" ${ }^{80}$ U 1991. godinu, koja će tu domovinu do kraja uništiti, njegov režim ulazi dodatno konsolidovan, poprimajući karakteristično obličje prepoznatljivo tokom čitave naredne decenije njegove vlasti.

Vladimir Petrović

THE ROLE OF THE MEDIA IN CONSOLIDATION OF POWER OF SLOBODAN MILOŠEVIĆ

\section{Summary}

The article deals with the role of media in consolidation of the regime of Slobodan Milošević. It provides the overview of the media systems of socialist Yugoslavia and of the development in this sphere after the death of Josip Broz Tito, with particular emphasis of the realignment of the main Serbian media before, during and after the Eighth Session of the Central Committee of the League of Communists of Serbia and their subsequent support for Slobodan Milošević and the creation of his regime.

${ }^{80}$ Cit. prema: S. Antonić, n. d., 112. 